\title{
Haem oxygenase-1 plays a central role in NNK-mediated lung carcinogenesis
}

\author{
M-Y. Li*, J. Yip*, M.K.Y. Hsin*, T.S.K. Mok ${ }^{\#}$ Y. Wu ${ }^{\mp,+}$, M.J. Underwood* and G.G. Chen*
}

ABSTRACT: The tobacco-specific nitrosamine, 4-(N-methyl-N-nitrosoamino)-1-(3-pyridyl)-1butanone (NNK), is a potent lung cancer inducer. However, how NNK induces lung cancer is still largely unknown.

Haem oxygenase (HO)-1 was evaluated in 30 pairs of lung cancer tumour samples and matched nontumour tissues from patients with a history of cigarette smoking. Expression of HO-1, p21 ${ }^{\mathrm{Cip} 1 / \text { Waf1/Cid1 }}$ (p21), B-cell lymphoma (Bcl)-2 family members, mitogen-activated protein kinase and nuclear factor (NF)-кB was also studied in lung cancer cells treated with NNK.

The levels of HO-1 and p21 were significantly increased in lung tumour tissues. There was a positive relationship between these two proteins in the tumour. NNK stimulated lung cell proliferation and elevated the levels of HO-1, p21, inhibitor of apoptosis protein (C-IAP)2 and Bcl-2, but downregulated Bad. These effects of NNK were blocked by zinc protoporphyrin-XII, an HO-1 inhibitor. The NNK-mediated expression of HO-1 was governed by NF- $\mathrm{KB}$ and extracellular signal-regulated kinase $1 / 2$, since blocking either of these prevented the stimulatory effect of NNK on HO-1, as well as molecules downstream of HO-1, such as p21, c-IAP2, Bcl-2 and Bad.

In conclusion, haem oxygenase-1 plays a central role in NNK-mediated cell proliferation by promoting the expression of $\mathrm{p} 21^{\mathrm{Cip} 1 / \mathrm{Waf} 1 / \mathrm{Cid} 1}$, inhibitor of apoptosis protein 2 and $\mathrm{B}$-cell lymphoma-2 but inhibiting the activity of Bad. Nuclear factor- $\mathrm{B}$ and extracellular signal-regulated kinase 1/2 function upstream of haem oxygenase-1. Therefore, haem oxygenase-1 is likely to be a potential target in the treatment of smoking-related lung cancer.

KEYWORDS: Extracellular signal-regulated kinase, haem oxygenase-1, lung cancer, NNK, nuclear factor-кB

moking is the single most extensively documented risk factor for all histological types of lung cancer [1]. Among the numerous toxic and carcinogenic agents in tobacco products, nicotine-derived 4 -( $N$-methyl$\mathrm{N}$-nitrosoamino)-1-(3-pyridyl)-1-butanone (NNK) is the most potent carcinogen [2,3]. The total dose of NNK that is experienced by a smoker in a lifetime of smoking is remarkably close to the lowest dose that is shown to induce lung cancer in rats [3]. Clearly, NNK is a major contributor to lung carcinogenesis in smokers and passive smokers $[4,5]$.

The kinase activities of a broad range of cyclin/ cyclin-dependent kinase (CDK) complexes in response to antimitogenic signals or DNA damage are directly blocked by p21 Cip1/Waf1/Cid1 (p21) [6]. The cell cycle can be positively or negatively regulated by $\mathrm{p} 21$ and the roe, of $\mathrm{p} 21$ role in carcinogenesis is inconsistent. The level of p21 is increased in various human cancers, such as glioma cell, breast, bladder and pancreatic cancers $[7,8]$. The haem oxygenase (HO) system controls the rate-limiting step in haem catabolism. Three isoforms have been described: $\mathrm{HO}-2$ and $\mathrm{HO}-3$ are primarily constitutive, whereas $\mathrm{HO}-1$ is highly inducible [9]. HO-1 has been shown to be associated with cell proliferation and growth and it participates in the pathogenesis of several types of cancers. An elevated expression or increased activity of HO-1 is associated with cellular proliferation in some tumours, such as prostate cancer, renal adenocarcinoma, gastric cancer and papillary thyroid cancer [10-13]. There is currently no work that describes the relationship between p21 and HO-1 in lung cancer.

Nuclear factor (NF)- $\kappa \mathrm{B}$ is a collective designation for a family of highly regulated dimeric transcription factors. In resting cells, NF- $\mathrm{KB}$, prototypically a heterodimer of p50 and p65 subunits, resides in the cytoplasm in an inactive form that is bound to the inhibitory subunit IкB. Upon cellular activation, I $\mathrm{KB}$ is phosphorylated by an IкB kinase complex and proteolytically degraded by proteasomes, leading to the activation of $N F-\kappa B$ [14]. NF- $\kappa B$ then translocates into the

\section{AFFILIATIONS}

Depts of *Surgery and

${ }^{\#}$ Clinical Oncology, The Chinese University of Hong Kong, Prince of Wales Hospital, Shatin, Hong Kong, 'Lung Cancer Research Institute, and ${ }^{+}$Cancer Center, Guangdong Provincial People's Hospital, Guangdong, Guangzhou, China.

CORRESPONDENCE

G.G. Chen

Dept of Surgery

The Chinese University of Hong Kong Prince of Wales Hospital

Shatin

New Territories

Hong Kong

Fax: 85226450605

E-mail: gchen@cuhk.edu.hk

Received:

April 282008

Accepted:

May 192008

\section{SUPPORT STATEMENT}

The study was in part supported by a direct grant (2041304) from the

Chinese University of Hong Kong.

STATEMENT OF INTEREST

None declared.

European Respiratory Journa Print ISSN 0903-1936 Online ISSN 1399-3003 
nucleus, where it binds to the $\kappa$ B-binding motifs in the promoters or enhancers of genes. NF- $\mathrm{\kappa B}$ can regulate cell proliferation, apoptosis and cell migration, and it is constitutively activated in several types of cancer cells [15, 16]. The mitogen-activated protein kinase (MAPK) family of proteins, including c-Jun $\mathrm{NH}_{2}$-terminal kinase (JNK), extracellular signal-regulated kinase (ERK) and p38 MAPK, play an important role in cell survival and apoptosis. The activation of the MAPK pathway can be either anti-apoptotic or proapoptotic, depending on the cellular context [17-19]. Considering the tumour-promoting effect of NNK in the lung, the aim of the present study was to investigate the roles of NF$\kappa \mathrm{B}$ and MAPK in NNK-mediated lung carcinogenesis.

In the present study, HO-1 was found to be constitutively expressed in human lung tumour tissues and was shown to play a central role in NNK-mediated cell proliferation. ERK and NF- $\kappa \mathrm{B}$ may function upstream of HO-1, whereas p21 is downstream of HO-1. The pro-proliferative HO-1 induced by NNK may finalise its effect via increasing B-cell lymphoma (Bcl)-2 but decreasing Bad. Blocking HO-1 significantly prevents the effect of NNK on lung cells.

\section{MATERIALS AND METHODS}

\section{Reagents}

NNK was purchased from Chemsyn Science Laboratories (Lenexa, KS, USA). NF-кB SN50 was obtained from CN Biosciences (La Jolla, CA, USA). The protease inhibitor cocktail and fluorescein isothiocyanate-conjugated immunoglobulins were supplied by Sigma-Aldrich Co. (St Louis, MO, USA). The

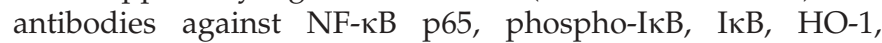
inhibitor of apoptosis protein (c-IAP)2, p38 and actin, and horseradish peroxidase (HRP)-conjugated secondary antibodies were provided by Santa Cruz Biotechnology, Inc. (Santa Cruz, CA, USA). The antibodies against Bad, phospho-Bad (Ser136, Ser112 and Ser155), phospho-ERK1/2, phospho-stressactivated protein kinase (SAPK)/JNK, phospho-p38 and ERK1/2 were from Cell Signaling Technology (Beverly, MA, USA). The antibodies against Bcl-2, p21 and SAPK/JNK were supplied from ZYMED ${ }_{\Re}$ Laboratories (South San Francisco, CA, USA). Propidium iodide (PI) and the ProLong Antifade solution were from Molecular Probes (Eugene, OR, USA). The colorimetric enzyme immunoassay kit for NF- $\mathrm{kB}$ was purchased from Oxford Biomedical Research (Oxford, MI, USA). Pierce SuperBlock was obtained from Pierce Biotechnology (Rockford, IL, USA). The VECTOR ImmPRESS universal antibody kit and biotinylated secondary antibodies were provided by Vector Laboratories (Burlingame, CA, USA).

\section{Human lung tissue and immunohistochemistry}

In total, 30 pairs of human lung tumour and nontumour tissues were obtained from lung cancer patients who underwent surgical resection in the Prince of Wales Hospital (Shatin, Hong Kong). Tumour tissue samples were taken from the central part of the tumours. Of the 30 patients, 17 were current cigarette smokers with an average smoking history of $35 \mathrm{yrs}$ and the other 13 patients were previous cigarette smokers with an average smoking history of 28 yrs. All tumour and nontumour tissue specimens were confirmed by histological examination. The tissue samples were stored in a liquid nitrogen tank until the experiments were performed. The samples included 10 pairs of squamous cell carcinoma tissues, 10 pairs of adenocarcinoma tissues, five pairs of large cell carcinoma tissues and five pairs of poorly differentiated carcinoma tissues. The tissues were sectioned and immunohistochemical staining was performed as previously described [20]. Briefly, after the section was blocked with Pierce SuperBlock supplemented with $0.05 \%$ Tween-20 (SBT), it was incubated with primary antibodies (p21 and HO-1) overnight. For the p21 antibody, tissue sections were treated with the ImmPRESS reagent. For the HO-1 antibody, the biotinylated secondary antibody was used in SBT. The sections were examined using the Zeiss Spot imaging system (Carl Zeiss, Jena, Germany).

\section{Cell culture}

The human nonsmall cell lung cancer (NSCLC) cells, NCI-H23, were grown in $100-\mathrm{mm}$ tissue culture disks as previously described [19].

\section{Assessment of cell proliferation and death}

Cell proliferation was measured with dimethylthiazolyldiphenyltetrazolium-bromide (MTT) as previously described [19]. Cell proliferation was further confirmed by bromodeoxyuridine labelling of DNA, performed according to the manufacturer's instructions (Roche Applied Science, Penzberg, Germany). Apoptosis was determined via the flow diagram of the APO-DIRECT ${ }^{\mathrm{TM}}$ apoptosis kit (Chemicon international, San Diego, CA, USA), as previously described [19].

\section{Fluorescence-immunohistochemical staining and microscopy}

Fluorescence-immunohistochemical staining was performed as described previously [21]. For p21, the nucleus was counterstained with $600 \mathrm{nM}$ 4,6-diamino-2-phenylindole. For NF-кB, the nucleus was counterstained with $0.5 \mu \mathrm{g} \cdot \mathrm{mL}^{-1}$ propidium iodide. The stained cells were examined using the Zeiss Spot imaging system.

\section{NF- $\kappa B$ transcriptional activity assay}

An NF-кB ELISA kit (Oxford Biomedical Research) was used. According to the manufacturer's protocol, the nuclear protein samples were diluted at $0.2 \mu \mathrm{g} \cdot \mu \mathrm{L}^{-1}$ in dilution buffer and incubated in 96-well plates that were pre-coated with an immobilised oligonucleotide containing a consensus binding

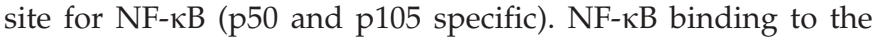
target oligonucleotide was detected by incubation with the primary antibody specific for the activated form of NF- $\mathrm{BB}$ ( $\mathrm{p} 50$ and p105 specific) followed by the anti-immunoglobulin-G HRP conjugate and developing solution. The plate was placed in a colorimetric plate reader and read at $450 \mathrm{~nm}$ after the colour had developed and the reaction was finished.

\section{Western blotting}

The cytosolic and nuclear protein fractions and total protein were isolated and Western blot analysis was performed as previously described [21]. Quantification of protein was carried out by densitometry analysis and the results were presented as relative intensities, with actin normalisation for total and cytosolic protein and lamin B normalisation for nuclear protein. 


\section{Statistical analysis}

The Wilcoxon signed ranks test was used to compare the differences in p21 and HO-1 expression between tumour and nontumour lung tissues. The Chi-squared test was used to study the correlation of p21 and HO-1 expression in tumour tissues. In the cell line study, the data were presented as mean $\pm S D$, with at least three separate determinations for each group. The differences between the groups were examined for statistical significance using a one-way ANOVA followed by unpaired t-test. A value of $\mathrm{p}<0.05$ was considered to indicate a statistically significant difference.

\section{RESULTS}

\section{HO-1 and p21 expression in lung tumour and nontumour tissues}

HO-1 and p21 expression was evaluated in 30 pairs of lung tumour and nontumour tissues. The scores of the immunohistochemical staining (table 1) showed that HO-1 and p21 levels were significantly increased in the tumour tissues compared with the nontumour tissues (both $\mathrm{p}<0.001$ ). There was a positive relationship between $\mathrm{HO}-1$ and $\mathrm{p} 21$ in tumour tissues $(\mathrm{p}<0.01)$. The expression of $\mathrm{HO}-1$ and p21 was obviously increased in tumour tissues compared with nontumour tissues (fig. 1). HO-1 was found in both the nucleus and the cytoplasm but p21 was mainly detected in the nucleus of the tumour tissues (fig. 1i-p).

\section{NNK-induced human lung cancer cell proliferation}

To investigate the effects of NNK on the proliferation of human lung cancer cells, cell proliferation was analysed by the MTT assay. NNK significantly increased the cell proliferation of the NCI-H23 cells in a time-dependent manner (fig. 2a). It appeared that the effect of NNK reached a plateau after its concentration reached a level of $>10 \mu \mathrm{M}$. Consistent with the MTT assay results, the DNA synthesis assay also showed the promoting effect of $10 \mu \mathrm{M}$ NNK on cell proliferation in a timedependent manner (fig. $2 b$ ). It was reported that $7 \mu \mathrm{M}$ of NNK corresponded to the approximate amount found in one pack of cigarettes [22]. NNK can reduce the pulmonary cytotoxicity due to attack or damage [23], which might facilitate the chronic deposit of a higher amount of NNK or its metabolites locally. Considering these facts and the dose-response curve of NNK obtained in the present study, $10 \mu \mathrm{M}$ NNK was used in all subsequent experiments.

\section{Upregulation of HO-1, p21 and c-IAP2 by NNK and the effect of NNK on Bcl-2 and Bad expression}

Western blotting revealed that the levels of HO-1, p21 and cIAP2 proteins were upregulated in a time-dependent manner by NNK (fig. 3a and b). The increased level of HO-1 could be detected as early as $1 \mathrm{~h}$ after NNK treatment. A clear increase in p21 was not observed until $2 \mathrm{~h}$ after the treatment. The upregulated c-IAP2 protein expression appeared to occur much later (fig. 3a and b) and the increased expression of HO-1 and p21 proteins occurred at earlier time-points. Western blot results also clearly showed that NNK upregulated p21 expression in the nucleus (fig. $3 c$ and d). The accumulation of p21 in the nucleus, due to NNK treatment, was further supported by the results of p21 fluorescence immunostaining (fig. 4), which is consistent with the results of the immunohistochemical staining of p21 in the tumour tissue (fig. 1i-p).
Mammalian Bcl-2 and its closest relatives, such as $\mathrm{Bcl}-\mathrm{X}_{\mathrm{L}}$ Bcl-w, Mcl-1 and A1, promote cell survival. In contrast, other members of the family, such as Bax, Bid, Bak and Bad, induce cell death [24]. Biologically active Bad is in a dephosphorylated form and interacts with Bcl-2 and Bcl- $X_{\mathrm{L}}$ to suppress their antiapoptotic function, whereas the inactive form of Bad is highly phosphorylated. The inactive form binds to 14-3-3 scaffold proteins and, thus, cannot interact with Bcl-2 or Bcl- $\mathrm{X}_{\mathrm{L}}$ [25]. Results of the present study showed that NNK downregulated Bad expression and upregulated Bcl-2 expression in NCI-H23 cells in a time-dependent manner. The decreased Bad expression was obvious $2 \mathrm{~h}$ after NNK treatment but the increased Bcl-2 was not observed until 4 or $8 \mathrm{~h}$ after the treatment (fig. $3 \mathrm{a}$ and $b$ ), which indicates that the former occurred much earlier than the latter in lung cancer cells that were treated by NNK. NNK enhanced the levels of phospho-Bad (Ser112, Ser136 and Ser155; fig. 3c and d), which indicates that Bad was inactivated by NNK.

\section{HO-1 functions as an upstream molecule to regulate p21 and apoptosis}

Among HO-1, p21 and c-IAP2, the increased expression of HO-1 occurred at the earliest time-point (fig. 3a), suggesting that the HO-1 signal was upstream of other molecular events. To confirm this, zinc protoporphyrin (ZnPP)-XII, a specific inhibitor of HO-1, was applied to block HO-1 expression. The results showed that ZnPP-XII significantly inhibited not only HO-1 expression but also p21 and c-IAP2 expression in cells treated with NNK (fig. $5 \mathrm{a}$ and b), indicating that HO-1 is necessary for the maximal expression of p21 and c-IAP2 in NNK-treated cells. Furthermore, p21 fluorescence immunostaining demonstrated that the effect of NNK on p21 relocalisation and accumulation in the nucleus could be blocked by ZnPP-XII (fig. 4), which provides another piece of evidence that HO-1 may function to regulate $\mathrm{p} 21$. The inhibition of HO-1 by ZnPP-XII significantly blocked NNKinduced cell proliferation (fig. 5c). In addition, such an inhibition also significantly promoted cellular apoptosis even in the presence of NNK (fig. 6). These data clearly support the hypothesis that $\mathrm{HO}-1$, as well as p21 downstream, play positive roles in NNK-induced cell proliferation.

\section{Activation of NF- $\kappa B$ and MAPK in NNK-treated NCI-H23 cells}

$\mathrm{NF}-\kappa \mathrm{B}$ is constitutively activated in several types of cancer cells $[15,16]$. In addition, previous studies have shown that NNK activates NF- $\kappa B$ in macrophages [26] and that $N F-\kappa B$ is involved in the growth of colon cancer and oral cancer cells $[27,28]$. However, few studies have addressed the relationship between NNK and NF- $\kappa B$ in lung cancer. Therefore, the current authors examined whether NF- $\kappa B$ activation could be induced by NNK in NCI-H23 lung cancer cells. It was found that lung cancer cells expressed the p65 subunit of NF- $\kappa B$ constitutively (fig. 7a-g). NNK not only upregulated the expression of p65 protein but also increased its translocation into the nucleus, which was detectable as early as $30 \mathrm{~min}$ after the treatment and peaked $2 \mathrm{~h}$ after the treatment (fig. $7 \mathrm{a}$ and b). The translocation of p65 into the nucleus was confirmed by immunofluorescence assays (fig. 7c-f). The profiles of elevated p65 protein and its nuclear translocation were further supported by a time-course study of NF- $\kappa B$ transcriptional activity, in which activity peaked $2 \mathrm{~h}$ after the treatment 


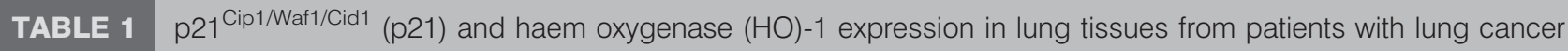

\begin{tabular}{|c|c|c|c|c|c|c|}
\hline \multirow[t]{2}{*}{ Tumour type } & \multirow{2}{*}{$\begin{array}{l}\text { Patient } \\
\text { number }\end{array}$} & \multicolumn{2}{|c|}{ p21 staining score ${ }^{\#}$} & \multicolumn{2}{|c|}{ HO-1 staining score ${ }^{\#}$} & \multirow[t]{2}{*}{ p-value } \\
\hline & & Tumour & Nontumour & Tumour & Nontumour & \\
\hline
\end{tabular}

Squamous cell carcinoma

Adenocarcinoma

Adenocarcinoma

Large cell carcinoma

1
2
3
4
5
6
7
8
9
10

3
4
1
4
1
0
1
1
4
3

1
2
0
1
0
0
0
0
1
0

$\begin{array}{ll}1 & 0 \\ 1 & 0 \\ 0 & 0 \\ 1 & 0 \\ 1 & 0 \\ 0 & 0 \\ 1 & 0 \\ 0 & 0 \\ 0 & 0 \\ 2 & 0\end{array}$

11
12
13
14
15
16
17
18
19
20

2
2
2
1
1
3
2
2
2
2 $\quad$

$\begin{array}{ll}2 & 0 \\ 2 & 0 \\ 4 & 0 \\ 1 & 0 \\ 0 & 0 \\ 0 & 0 \\ 1 & 0 \\ 1 & 0 \\ 1 & 0 \\ 1 & 0\end{array}$

$\begin{array}{ll} & 21 \\ & 22 \\ & 23 \\ 24 & 25\end{array}$

$\begin{array}{ll}21 & 4 \\ 22 & 2 \\ 23 & 5 \\ 24 & 3 \\ 25 & 2\end{array}$

Poorly differentiated

carcinoma

$\begin{array}{ll}26 & 3 \\ 27 & 2 \\ 28 & 2 \\ 29 & 2 \\ 30 & 3\end{array}$

p-value

$<0.001$

0

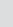

(1)

(1)

洒

(0)

$\begin{array}{ll}1 & 0 \\ 0 & 0 \\ 0 & 0 \\ 2 & 0 \\ 2 & 0\end{array}$

\footnotetext{
\#: according to distribution of positive staining as follows. 0: no staining; 1 : $<20 \%$ of cells; $2: 21-40 \%$ of cells; $3: 41-60 \%$ of cells; $4: 61-80 \%$ of cells; 5 : $>81 \%$ of cells.

$\because$ : Chi-squared test for p21 expression versus HO-1 expression in tumour tissue. ${ }^{+}$. Wilcoxon signed ranks test for tumour versus nontumour tissue.
}

(fig. 7g). Consistent with this, phospho (p)-IкB $\alpha$ also increased in the cytosol (fig. 7a and b). The increase of $\mathrm{p}-\mathrm{I \kappa \textrm {B }} \alpha$ in the cytosol may promote the translocation of NF- $\kappa \mathrm{B}$ into the nucleus [14].

Western blotting showed that NNK significantly increased phospho-ERK1/2 protein as early as $30 \mathrm{~min}$ after NNK treatment and the level peaked $60 \mathrm{~min}$ after treatment (fig. $7 \mathrm{~h}$ ), which suggests that the increase in ERK1/2 activation is an early event in the NNK-mediated signal pathway in lung cancer cells. However, p38 and SAPK/JNK activation were not altered by NNK in the cells that were tested.
Regulation of HO-1, p21, C-IAP2, Bad and Bcl-2 expression by the ERK and NF- $\kappa B$ inhibitors and ERK activation upstream of NF- $\boldsymbol{B} B$ in NNK-treated cells

As the results in figure 3 show, the levels of HO-1, p21, c-IAP2 and Bcl-2 proteins were enhanced by NNK. However, such a promoting effect was prevented by U0126, a specific inhibitor of ERK activation, or SN50, a specific inhibitor of NF- $\kappa$ B activation (fig. 8a and b). In contrast, the level of Bad was reduced by NNK (fig. 3). This reduction effect was inhibited by either U0126 or SN50 (fig. 8a and b). Hence, the present data suggest that the regulation of these proteins by NNK may require the activation of

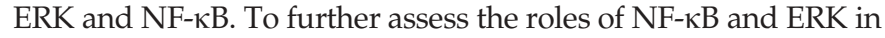



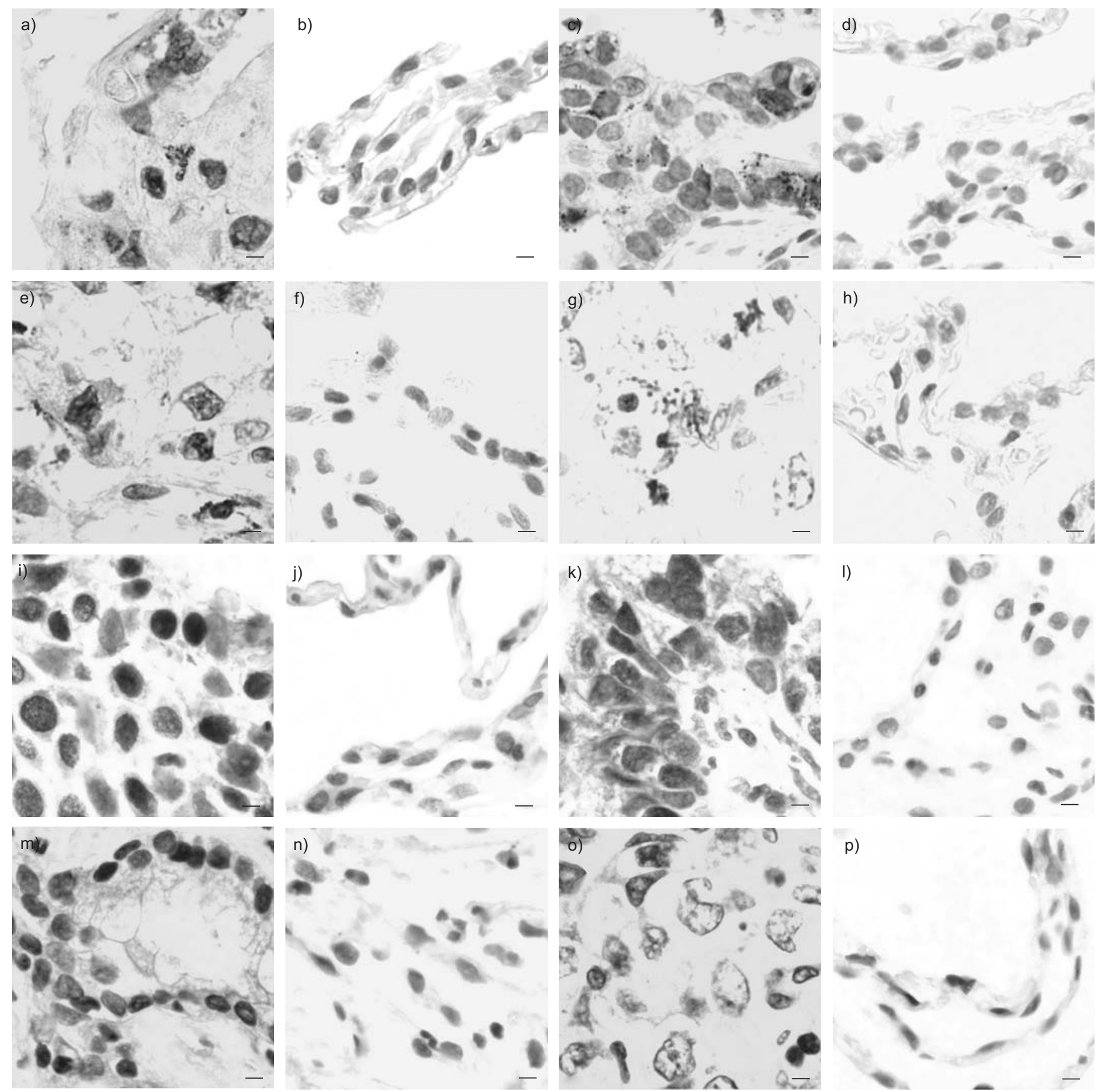

h)
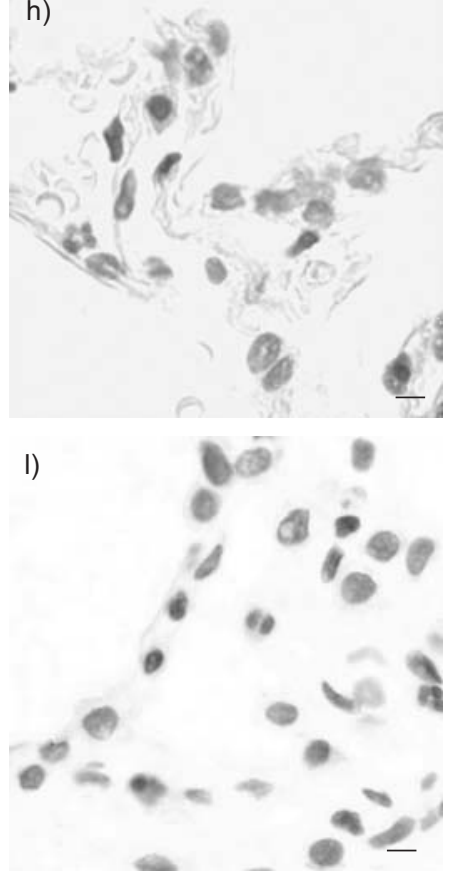

p)
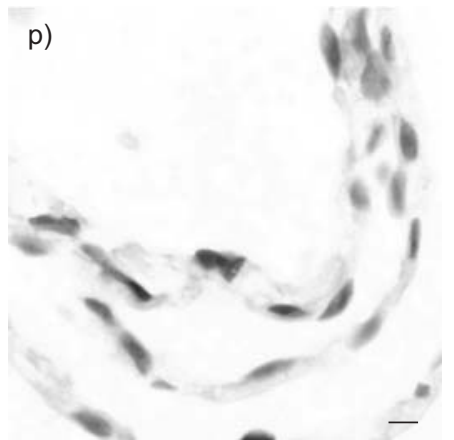

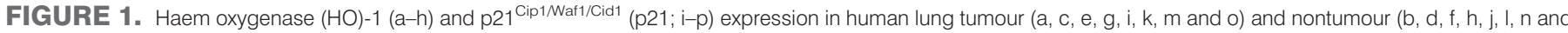
p) tissues. Representative immunohistochemical stainings showed a significant increase in $\mathrm{HO}-1$ levels in both the nucleus and the cytoplasm in the tumour tissues of all four types of lung cancers, compared with the matched nontumour tissues. The positive staining of p21 was mainly in the nucleus of the tumour tissues. a, b, i and j) Squamous cell carcinoma; c, d, k and I) adenocarcinoma; e, f, $m$ and n) large cell carcinoma; $g, h, o$ and p) poorly differentiated carcinoma. Scale bars $=5 \mu \mathrm{m}$.

NNK-treated cells, U0126 and SN50 were employed to study the relationship between the activity of NF- $\mathrm{KB}$ and ERK activation. It was found that both U0126 and SN50 significantly blocked NNKmediated NF- $\mathrm{KB}$ transcriptional activity, which resulted in the reduction of this activity to the control level (fig. 8c). NNKmediated ERK activation was prevented by U0126 but not by
SN50 (fig. 8d). Therefore, ERK activation probably functions upstream of NF- $\mathrm{KB}$ in the NNK-mediated pathway. This suggestion is in line with the time-course studies of ERK and NF- $\kappa \mathrm{B}$ (fig. 7), which showed that the maximal activity of NF- $\kappa \mathrm{B}$ that was induced by NNK occurred $2 \mathrm{~h}$ after NNK treatment, whereas the peak level of phospho-ERK was observed $1 \mathrm{~h}$ earlier. 

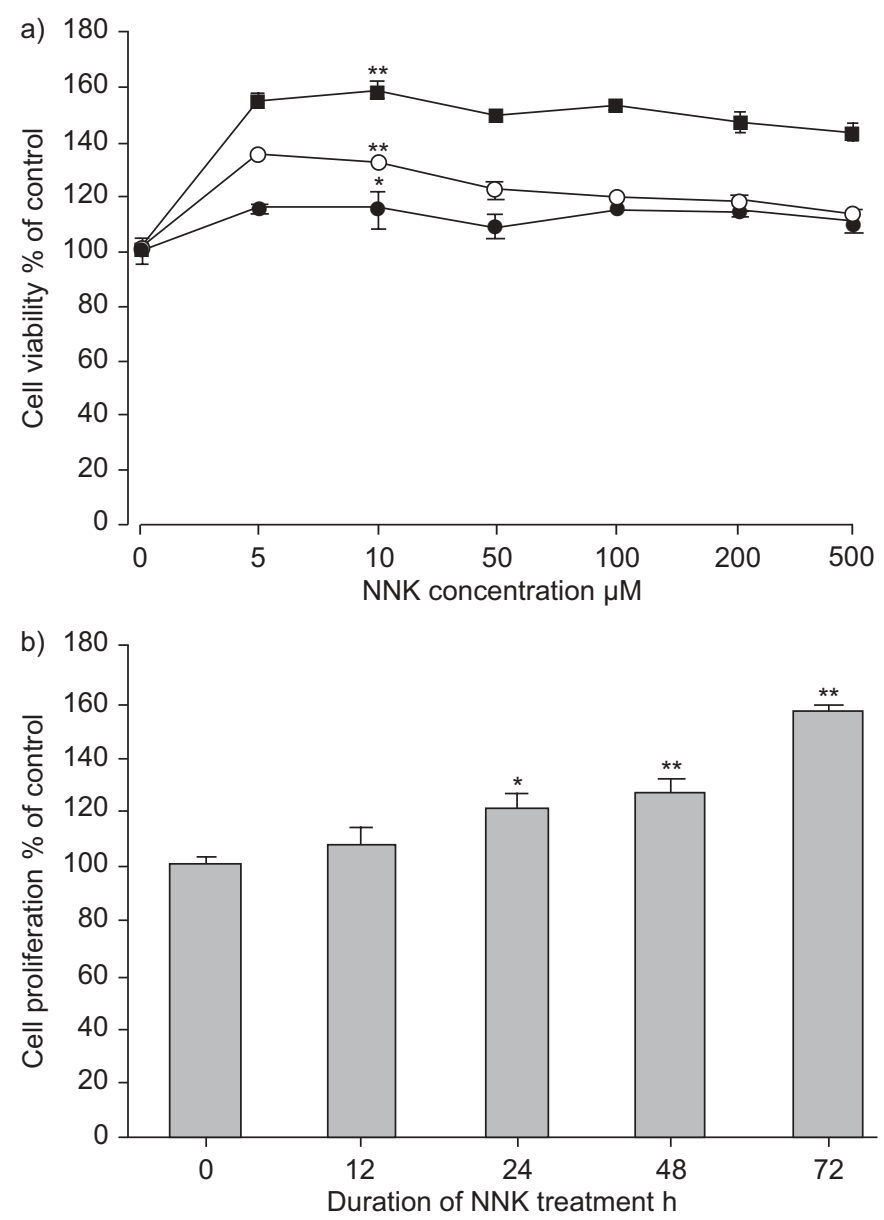

FIGURE 2. 4-(N-methyl-N-nitrosoamino)-1-(3-pyridyl)-1-butanone (NNK) induced the proliferation of lung cancer cells. a) Human nonsmall cell lung cancer cells, NCl-H23, were treated with NNK $(0-500 \mu \mathrm{M})$ for $24 \mathrm{~h}(\bullet), 48 \mathrm{~h}(\mathrm{O})$ and $72 \mathrm{~h}$ (匹). Cell proliferation was measured by the dimethylthiazolyl-diphenyltetrazoliumbromide assay and the data are expressed as percentages of the control culture conditions (0 $\mu \mathrm{M} N N K)$. b) NCl-H23 cells were treated with $10 \mu \mathrm{M}$ NNK for 0-72 h. Cell proliferation was determined by bromodeoxyuridine cell proliferation assay and the data are presented as percentages of the $0 \mathrm{~h}$ control conditions. All data are represented as the mean $\pm \mathrm{SD}$ for four replicates of each treatment. The experiments were repeated twice with similar results. Compared with untreated cells, there was a significant increase in cells after 24,48 and $72 \mathrm{~h}$ of treatment with $10 \mu \mathrm{M}$ NNK. ${ }^{*}: p<0.05 ;{ }^{* *}: p<0.01$

\section{DISCUSSION}

HO-1 participates in the development of some malignant tumours, such as gastric cancer and thyroid carcinoma [12, 13]. The inhibition of HO-1 reduces the growth of lung tumours in mice [29]. The present study found that $\mathrm{HO}-1$ was significantly increased in the lung tumour tissue of smokers and that the cigarette carcinogen NNK was able to stimulate the expression of HO-1 protein. This result suggests that an increase in HO-1 may be key in the development of cigarette smoking-related lung cancer, and this conclusion is reinforced by the findings that blocking HO-1 prevented NNK-induced cell proliferation and reduced the growth of lung cancer. In the current study, a variety of molecules upstream and downstream of HO-1 have been found to be associated with NNK treatment and this supports the hypothesis of a central role for HO-1 in NNKmediated lung carcinogenesis.

NF- $\kappa \mathrm{B}$ appears to be an upstream molecule in NNK-mediated HO-1 expression. As in many other types of cells $[15,16]$, there was constitutive NF- $\kappa \mathrm{B}$ activity in the NCI-H23 lung cancer cells. Despite the well-known pro-survival/growth effect of $\mathrm{NF}-\kappa \mathrm{B}$, there is very limited information on the relationship between NF- $\kappa \mathrm{B}$ and the tobacco-specific carcinogenic agent NNK in human lung cancer. The present study demonstrated that NNK increased the activity of NF- $\mathrm{KB}$ significantly, as evidenced by the increased levels of its p65 subunit, the nuclear translocation of p65 and the elevated transcriptional activity in NCI-H23 NSCLC cells. The elevated activity of NF$\kappa \mathrm{B}$ was accompanied by an increased proliferation and growth of lung cancer cells treated by NNK. This elevation of NF-кB activity was observed as early as $15 \mathrm{~min}$ after NNK treatment and the maximal effect was recorded $2 \mathrm{~h}$ after NNK treatment, which indicates that the increase in NF- $\mathrm{BB}$ activity was a relatively early event in the NNK-mediated signal transduction pathway. The nuclear NF- $\kappa \mathrm{B}$ transactivates a large body of genes that are involved in diverse cellular functions, such as cell proliferation, apoptosis inhibition, cell adhesion and cell migration [30]. These diverse cellular functions can be regulated by MAPK, the activity of which is closely associated with NF- $\mathrm{B}[12,13]$. In the present study, it was demonstrated that NNK significantly stimulated ERK activation in lung cancer cells. Furthermore, the time-course study demonstrated that the change in ERK preceded the increased NF- $\kappa$ B activity. This observation was further supported by the experiment that employed an ERK inhibitor (U0126) and an NF- $\mathrm{\kappa B}$ inhibitor (SN50). Both U0126 and SN50 effectively blocked most of the NF- $\kappa \mathrm{B}$ transcriptional activity that was induced by NNK. However, NNK-mediated increased ERK activation was prevented only by U0126 and not by SN50. Therefore, ERK appears to function upstream of NF- $\mathrm{KB}$ in NNK-treated NCI$\mathrm{H} 23$ cells. In fact, NNK has been documented to promote the activity of NF- $\mathrm{BB}$ in human bronchial epithelial cells [31], although it has not been shown which subunit of NF- $\kappa B$ contributes to the increased activity. The present study has indicated that NNK affects multiple steps related to the activity

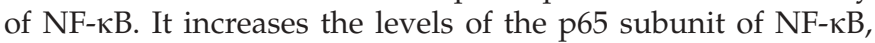
promotes p65 nuclear translocation and stimulates NF- $\kappa B$ transcriptional activity. The increased p65 subunit levels observed are supported by the fact that p65 protein is overexpressed in lung tissue samples of NSCLC [32]. A previous study failed to show that NNK can stimulate the activity of NF- $\mathrm{BB}$ in NSCLC cells [33]. However, the concentration of NNK that was used was $100 \mathrm{nM}$, which is much lower than the $10 \mu \mathrm{M}$ that was employed in the present study. The difference in the NNK concentration used is probably the factor that is responsible for the different results obtained. The concentration of $10 \mu \mathrm{M}$ NNK used in the present study is in line with a study that shows that the same concentration of NNK also promotes the activity of NF- $\kappa B$ [31]. More importantly, NNK at a concentration of $10 \mu \mathrm{M}$ is achievable in smokers [22, 23]. Concentrations of nicotine have been reported in the range of $10-100 \mu \mathrm{M}$ in serum [34] and even higher on the local mucosal surface [35].

The present study demonstrated that the level of HO-1 was governed by ERK and NF-אB, as both U0126 and SN50, potent 
a)

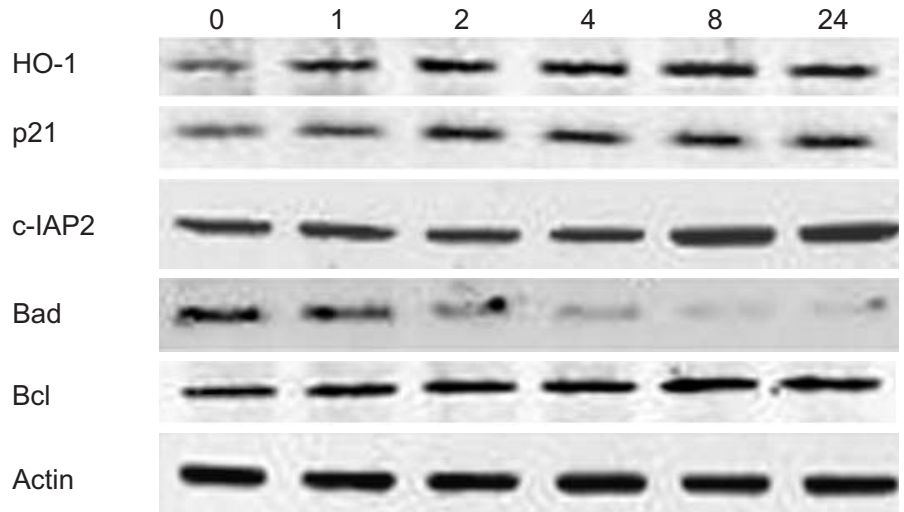

c)

Cytosolic p21

Nuclear p21

\section{Cytosolic} actin

Nuclear lamin B

p-Bad112
Control NNK
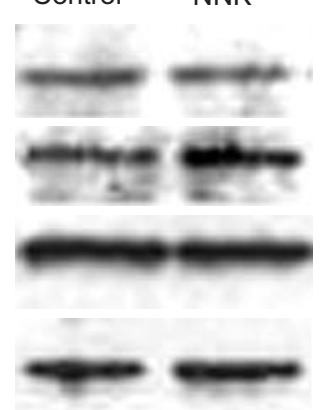

Actin

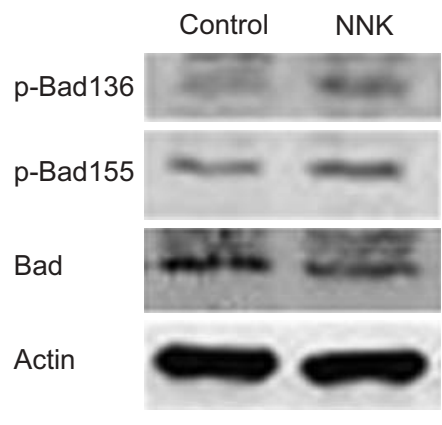

b)
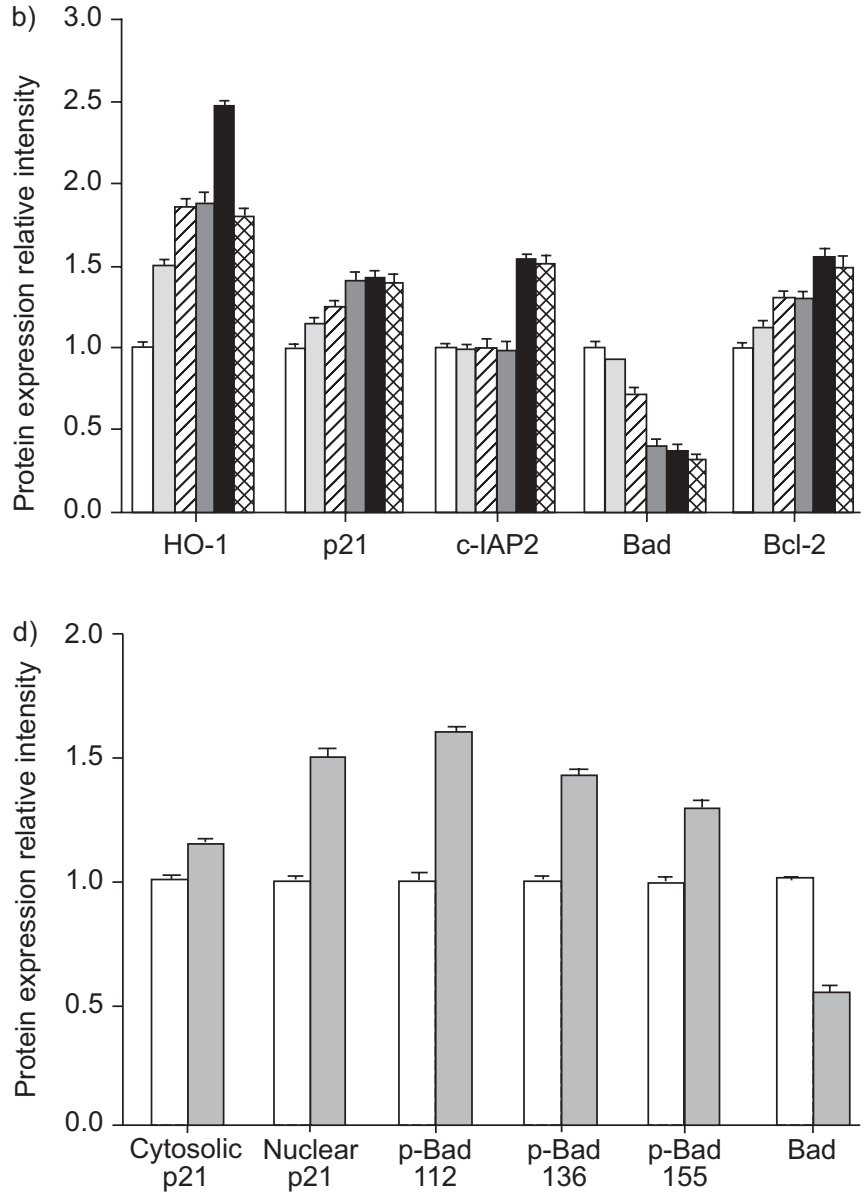

FIGURE 3. Upregulation of the expression of haem oxygenase (HO)-1, p21 $1^{\text {Cip1/Waf1/Cid1 }}$ (p21), inhibitor of apoptosis protein (c-IAP)2 and B-cell lymphoma (Bcl)-2, and downregulation of Bad in human nonsmall cell lung cancer cells (NCI-H23) treated with 4-(N-methyl-N-nitrosoamino)-1-(3-pyridyl)-1-butanone (NNK). a) Cells were treated with $10 \mu \mathrm{M}$ NNK for 0-24 h. Levels of HO-1 (32 kD), p21 (21 kD), c-IAP2 (70 kD), Bcl-2 (28 kD) and Bad (23 kD) were determined by Western blot. Equal loading was confirmed by probing with antibodies against actin $(43 \mathrm{kD})$. b) Summary of the relative intensity of protein bands. The experiments were repeated twice and similar results were obtained. $\square: 0$ h; $\mathbb{1}: 1$ h; $\mathbb{Z}: 2$ h; $\mathbf{m}: 4$ h; $: 8$ h; $: 24$ h. c) Cells were treated with $10 \mu \mathrm{M}$ NNK for $24 \mathrm{~h}$. Cells without treatment were set up as control. p21 expression in the cytosol and nucleus, three kinds of phospho-Bad (Ser112, Ser136 and Ser155; 23 kD) and total Bad expression were determined by Western blot. Equal loading was confirmed by probing with antibodies against actin in the cytosol and total protein and against lamin B (67 kD) in the nucleus. d) Summary of the relative intensity of protein bands. The experiments were repeated twice and similar results were obtained. $\square$ : control; $\square$ : NNK

inhibitors of ERK and $\mathrm{NF}-\kappa \mathrm{B}$ respectively, prevented the expression of HO-1 that was induced by NNK. These results strongly indicate that NF- $\kappa \mathrm{B}$ and ERK activation is necessary for NNK to stimulate the expression of HO-1 in the NSCLC cells tested. The current findings are supported by the observations that the MAPK pathway and NF- $\kappa B$ appear to be involved in HO-1 expression in response to diverse stimuli $[12,36]$, and that the inhibition of the ERK/MAPK pathway attenuates HO-1 expression [37].

The first molecule downstream of HO-1 in the NNK-mediated pathway is p21, which is defined as a negative cell cycle regulator because it binds CDKs and regulates the activity of these molecules in early G1 phase. In normal cells, the function of p21 is to ensure appropriate CDK inhibition during cell cycle progression. However, recent studies have demonstrated that p21 may also have an anti-apoptotic function, which enables the cells to proliferate under conditions that otherwise lead to apoptosis or arrest $[8,38]$. There has been no report of the relationship between p21 and lung cancer patients with cigarette-smoking history. In the present study, it has been demonstrated that nuclear p21 significantly increased in the lung tumour tissues from smokers, suggesting that p21 may play a role in lung cancer. This finding is in line with a recent study showing a positive role of p21 in lung cancer cell proliferation [39]. The current study has further revealed that there is a positive relationship between the expression of p21 and $\mathrm{HO}-1$ in lung cancer. The time-course study showed that the increase in $\mathrm{HO}-1$ occurred earlier than the elevated expression of p21 in NNK-treated cells. ZnPP-XII, an HO-1specific inhibitor, not only decreased HO-1 expression but also downregulated p21 expression in NNK-treated cells, which suggests that HO-1 functions upstream of p21. Previous studies of solid tumours have indicated that the overexpression of $\mathrm{HO}-1$ results in a significant increase in the level of p21 and that subsequently it renders tumour cells resistant to cell death stimulation $[12,13]$. Similar to HO-1, the increased level of p21 in the NNK-treated cells could also be inhibited by either ERK 

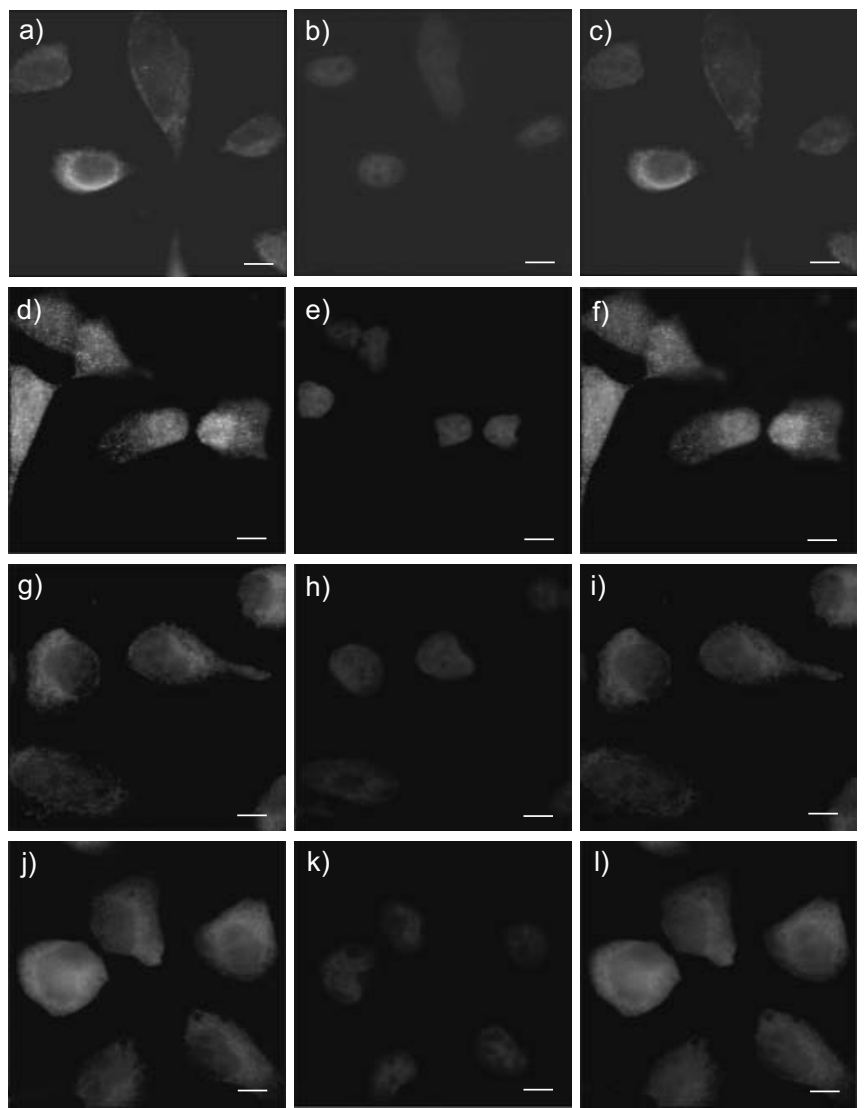

FIGURE 4. The nuclear distribution of p21 $1^{\mathrm{Cip} 1 / \text { Waf1/Cid1 }}(\mathrm{p} 21)$ in cells treated with 4-(N-methyl-N-nitrosoamino)-1-(3-pyridyl)-1-butanone (NNK) was blocked by the haem oxygenase (HO)-1 inhibitor, zinc protoporphyrin (ZnPP)-XII. a-c) Control with no treatment. d-f) Cells were treated with $10 \mu \mathrm{M} N N K$ for $24 \mathrm{~h}$, or g-i) pretreated with $20 \mu \mathrm{M}$ ZnPP-XII for 30 min, followed by $10 \mu \mathrm{M}$ NNK treatment for $24 \mathrm{~h}$. j-I) Cells treated with $20 \mu \mathrm{M}$ ZnPP-XII alone. An anti-p21 antibody was used in connection with a fluorescein isothiocyanate-conjugated secondary antibody (a, d, $\mathrm{g}$ and $\mathrm{j}$ ). For the counterstaining of the nucleus ( $\mathrm{b}, \mathrm{e}, \mathrm{h}$ and $\mathrm{k}$ ), 4,6-diamino-2phenylindole was used. The images are representative of three experiments. Scale bars $=2 \mu \mathrm{m}$.

inhibitor U0126 or NF-кB inhibitor SN50. The tumour-promoting effect of p21 is MAPK-dependent [8, 40]. Collectively, the current results demonstrate that $\mathrm{p} 21$ is a downstream molecule of HO- 1 and both HO-1 and p21 are governed by ERK and NF$\kappa \mathrm{B}$ in the NNK-mediated HO-1 pathway.

Another molecule that is possibly downstream of HO-1 in NNK-treated lung cancer cells is Bcl-2. NNK can stimulate the expression of Bcl-2 protein in NSCLC cells. Similar to the regulation of p21 by NNK, an increased level of Bcl-2 can be prevented by the ERK inhibitor U0126 and the NF- $\mathrm{KB}$ inhibitor SN50, which indicates that the increased level of $\mathrm{Bcl}-2$ is controlled by ERK and NF- $\kappa B$, both of which function upstream of HO-1. Therefore, ERK and NF- $\mathrm{B}$ may influence the level of Bcl-2 via the promotion of HO-1 in NSCLC cells. The role of $\mathrm{HO}-1$ in the regulation of $\mathrm{Bcl}-2$ is supported by the finding that the level of $\mathrm{Bcl}-2$ can be upregulated by the exogenous transfer of $\mathrm{HO}-1$ into cells [41]. In addition to $\mathrm{HO}-1$, the production of $\mathrm{Bcl}-2$ may also be regulated by $\mathrm{NF}-\kappa \mathrm{B}$ because the promoter region of $\mathrm{Bcl}-2$ contains binding sites for a)
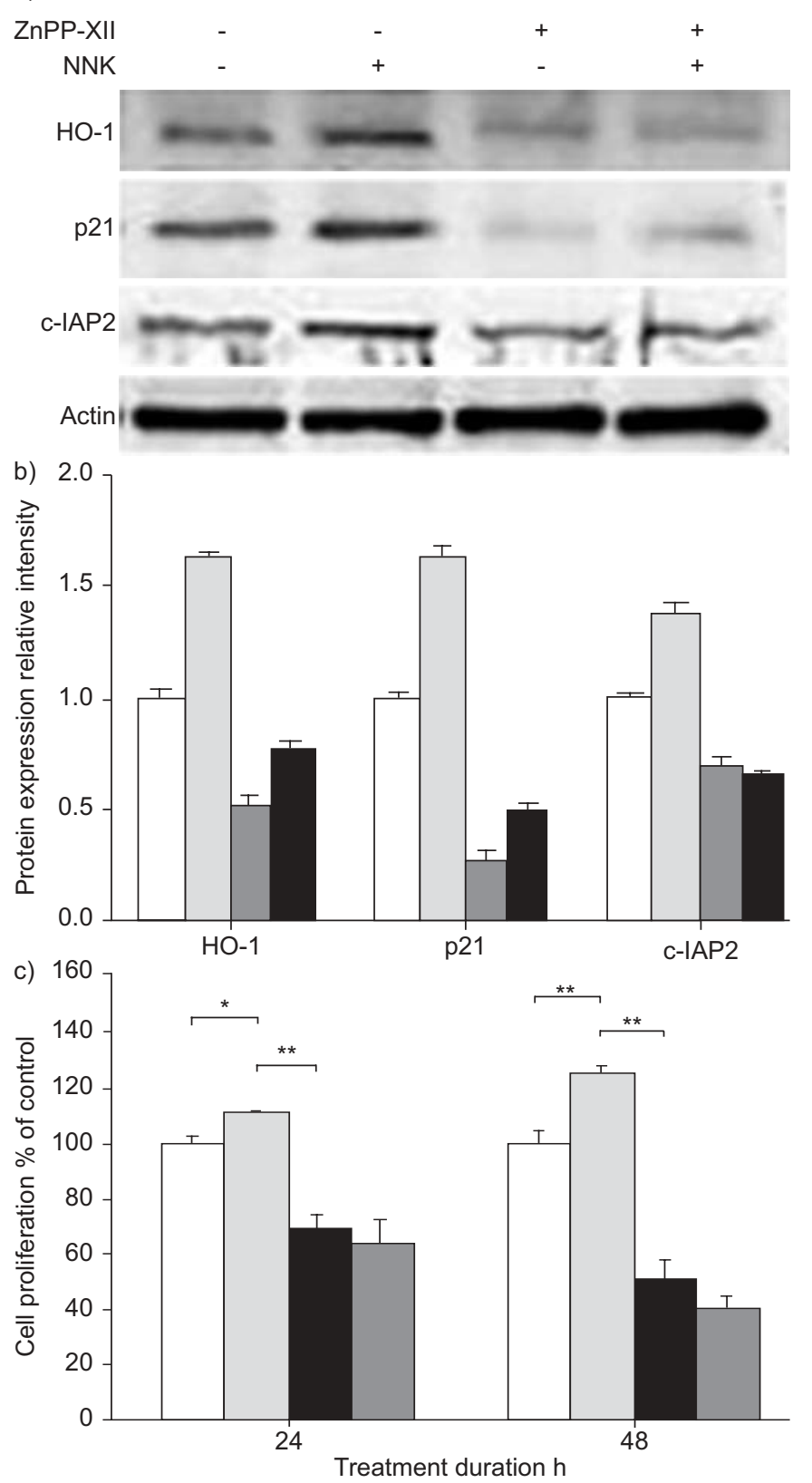

FIGURE 5. Blocking haem oxygenase $(\mathrm{HO})-1$ with the inhibitor zinc protoporphyrin (ZnPP)-XII prevented the effect of 4 -( $N$-methyl- $N$-nitrosoamino)-1(3-pyridyl)-1-butanone (NNK) and stimulated apoptosis. a) Cells were treated with $10 \mu \mathrm{M}$ NNK for $24 \mathrm{~h}$, or pre-treated with $20 \mu \mathrm{M}$ ZnPP-XII for $30 \mathrm{~min}$, followed by $10 \mu \mathrm{M} N N K$ treatment for $24 \mathrm{~h}$. Cells without treatment were set up as control. Levels of HO-1, p21 ${ }^{\text {Cip } 1 \text { Waf1/Cid1 }}$ (p21) and inhibitor of apoptosis protein (c-IAP)2 were determined by Western blot. Equal loading was confirmed by probing with antibodies against actin. b) Summary of the relative intensity of protein bands. The experiments were repeated twice and similar results were obtained. $\square$ : control; $\square$ : NNK alone; $\mathbf{a}:$ ZnPP-XII alone; $\mathbf{a n P P - X I l}$ and NNK. c) Cell proliferation was measured after 24 or $48 \mathrm{~h}$ by the dimethylthiazolyl-diphenyltetrazolium-bromide assay and the data are expressed as percentages of the control culture conditions (no treatment). The data are represented as the mean \pm SD for four replicates of each treatment. The experiments were repeated twice with similar results. There was a significant difference between control and NNK-treated cells and between NNKtreated cells and ZnPP-XII-treated cells. ${ }^{*}: p<0.05 ;{ }^{* *}: p<0.01$. 

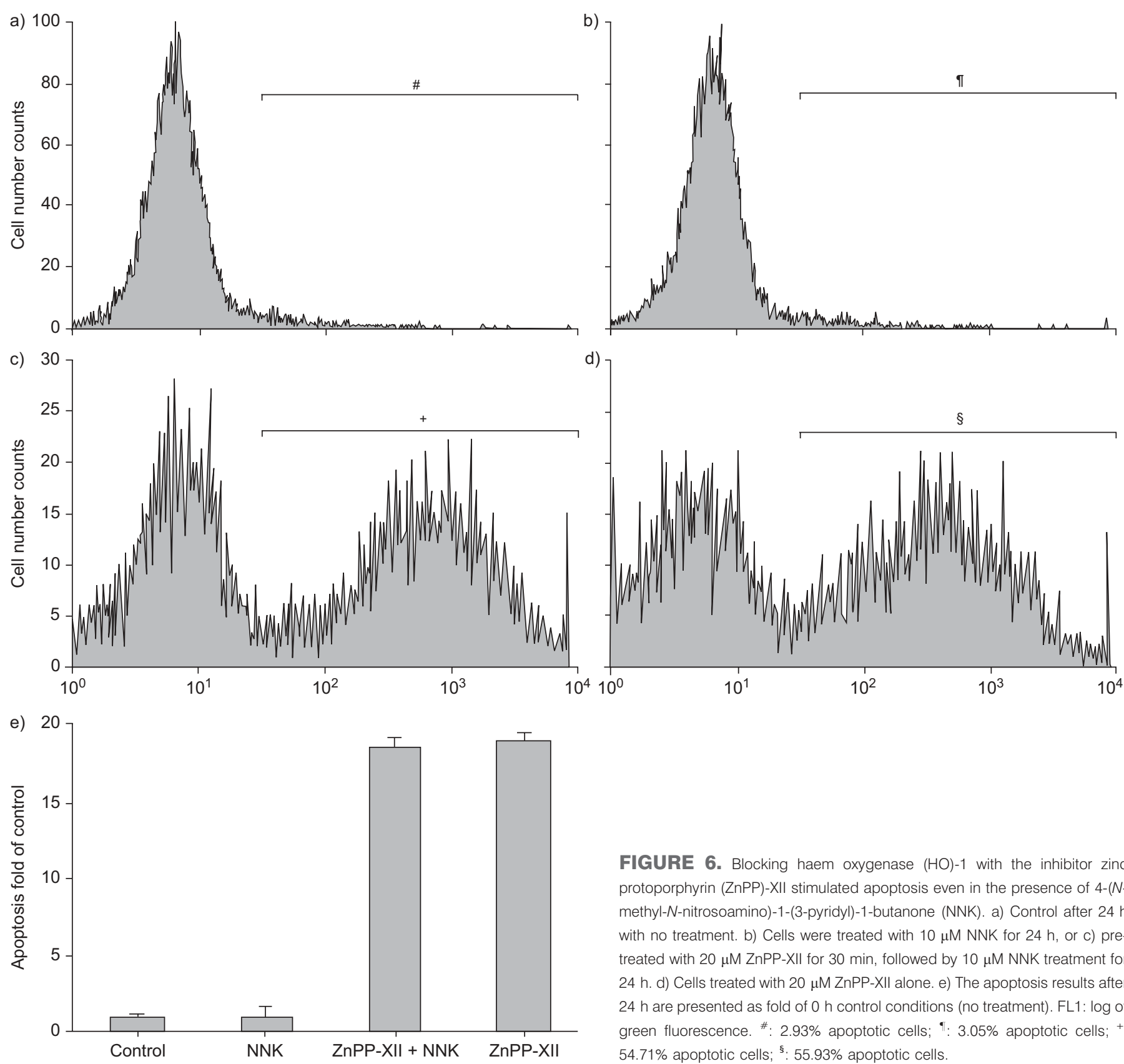

FIGURE 6. Blocking haem oxygenase $(\mathrm{HO})-1$ with the inhibitor zinc protoporphyrin (ZnPP)-XII stimulated apoptosis even in the presence of 4-(Nmethyl-N-nitrosoamino)-1-(3-pyridyl)-1-butanone (NNK). a) Control after $24 \mathrm{~h}$ with no treatment. b) Cells were treated with $10 \mu \mathrm{M} N N K$ for $24 \mathrm{~h}$, or C) pretreated with $20 \mu \mathrm{M}$ ZnPP-XII for 30 min, followed by $10 \mu \mathrm{M}$ NNK treatment for $24 \mathrm{~h}$. d) Cells treated with $20 \mu \mathrm{M}$ ZnPP-XIl alone. e) The apoptosis results after $24 \mathrm{~h}$ are presented as fold of $\mathrm{O} \mathrm{h}$ control conditions (no treatment). FL1: log of green fluorescence. ${ }^{\#}: 2.93 \%$ apoptotic cells; ${ }^{\text {}: ~} 3.05 \%$ apoptotic cells; ${ }^{+}$ $54.71 \%$ apoptotic cells; ${ }^{\text {s: }}$ 55.93\% apoptotic cells.

NF- $\kappa$ B. The stimulation of the binding site may induce the generation of Bcl-2 [42].

NNK has been shown to downregulate the expression of Bad but to upregulate the level of c-IAP2 in NSCLC cells. This is in agreement with the cell growth-promoting feature of NNK, as Bad can function to induce cell death whereas c-IAP2 can function to inhibit it. Biologically active Bad is in a dephosphorylated form and it interacts with $\mathrm{Bcl}-2$ and $\mathrm{Bcl}-\mathrm{X}_{\mathrm{L}}$ to suppress their anti-apoptotic function. In contrast, the inactive form of Bad is highly phosphorylated. It binds to 14-3-3 scaffold proteins and cannot interact with $\mathrm{Bcl}-2$ or $\mathrm{Bcl}-\mathrm{X}_{\mathrm{L}}$ [25]. Interestingly, NNK has been shown to strongly induce the phosphorylation of Bad at multiple sites, including Ser112, Ser136 and Ser155, and the phosphorylation of $\mathrm{Bad}$ is associated with the increased survival of human lung cancer cells [43]. The present study indicated that U0126 and SN50, potent inhibitors of ERK and NF- $\mathrm{KB}$ respectively, prevented the effect of NNK on Bad and c-IAP2 expression. c-IAP2 appears to be a downstream molecule of HO-1 and p21, as the expression of HO-1 and p21 precedes the increase in c-IAP2. Although the way in which HO-1 and p21 interact with c-IAP2 is not clear, the c-IAP molecule is known to participate in the anti-apoptotic pathway of ERK $[12,44]$.

In conclusion, the present study shows increased levels of haem oxygenase-1 in lung tumour tissues of smokers and NNKtreated cells, which suggests a positive role for this protein in smoking-mediated lung carcinogenesis. The NNK-mediated expression of haem oxygenase- 1 requires extracellular 
Time min

Nuclear p65

Cytosolic p65

Cytosolic p-ІкB $\alpha$

Cytosolic IKBo

Cytosolic actin

Nuclear lamin B

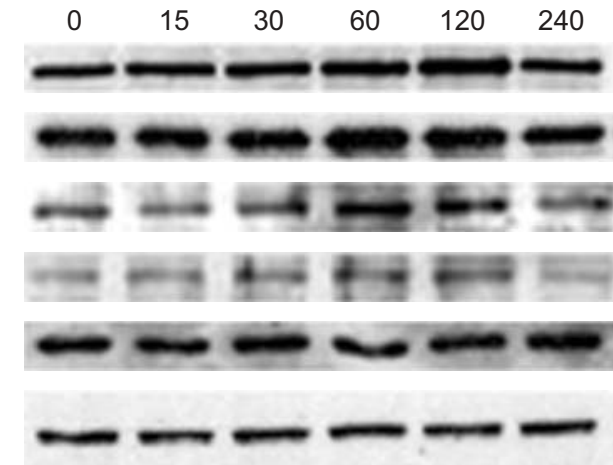

b) 2.0

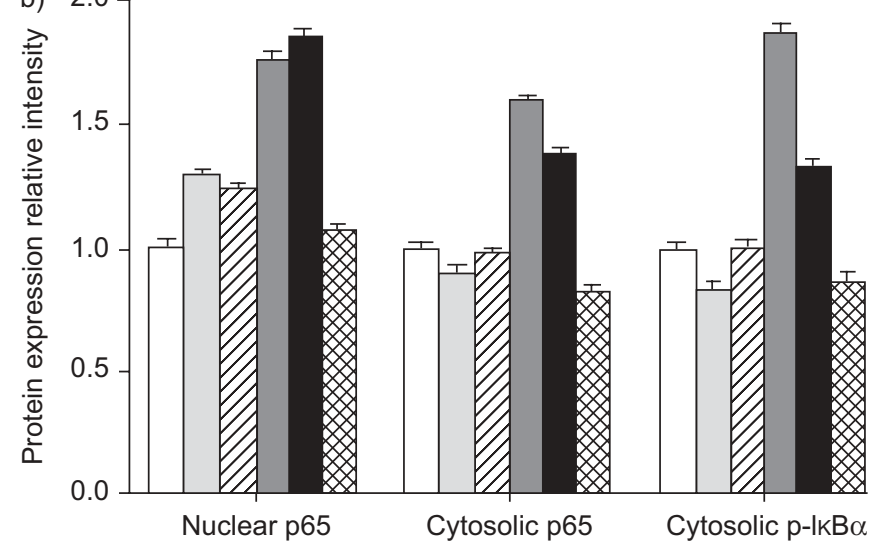

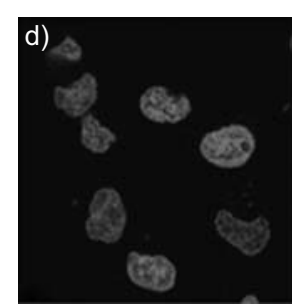

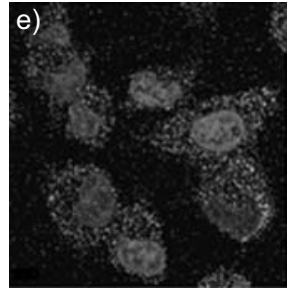

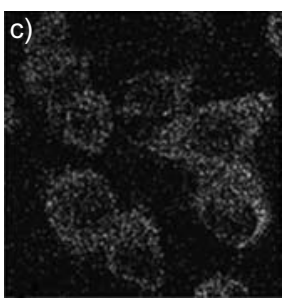

(1)
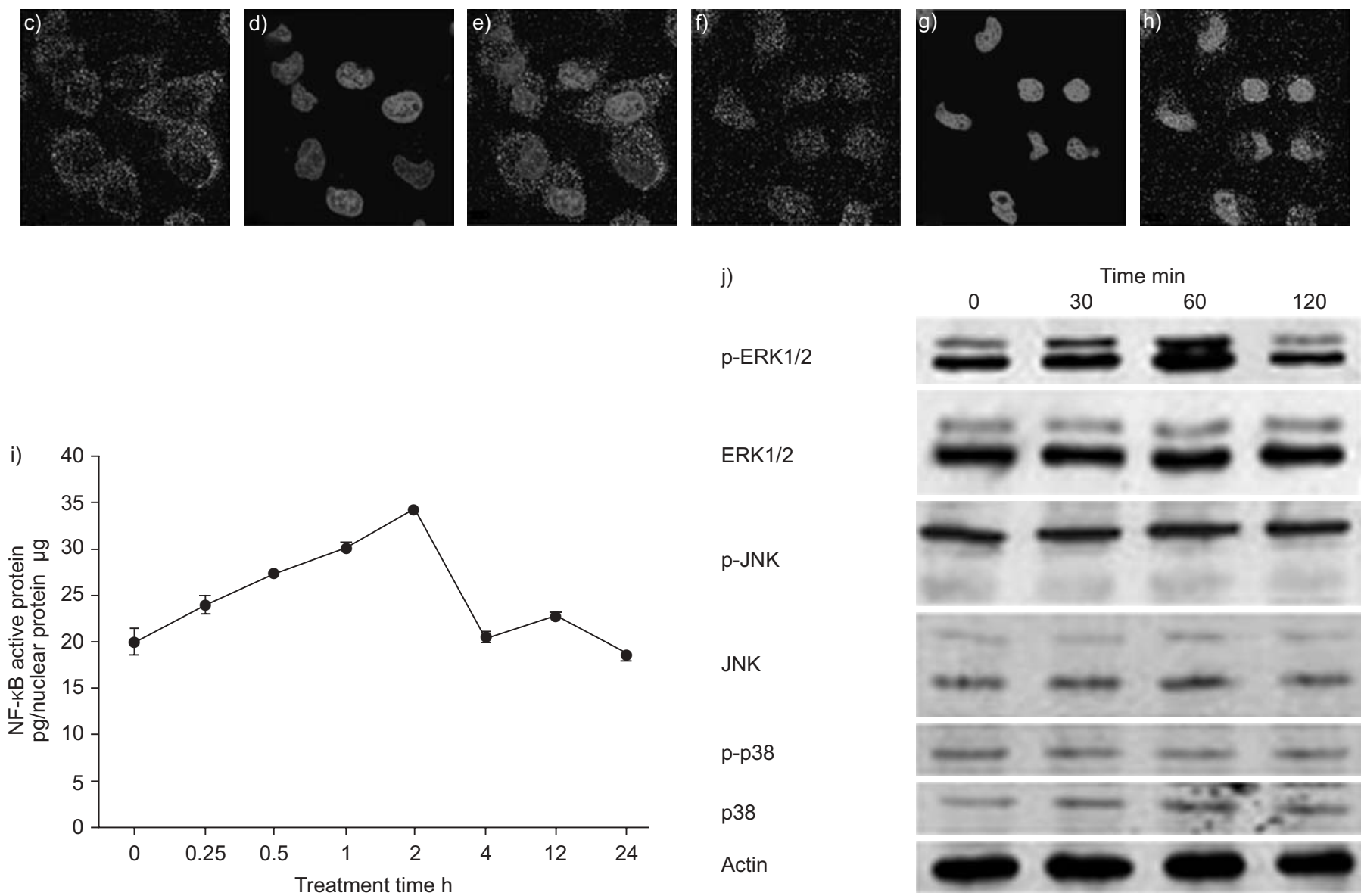

j)

p-ERK1/2

ERK1/2

Time min $30 \quad 60$ 120

\section{0}

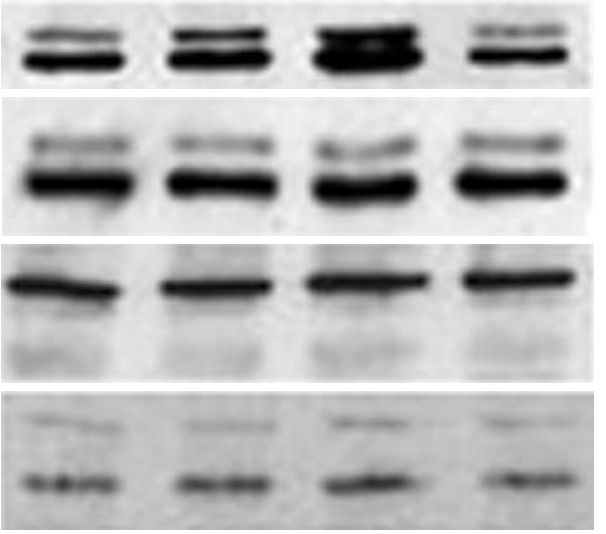

p-p38

p38

Actin

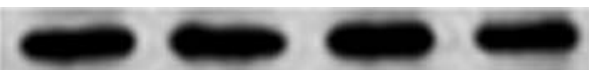

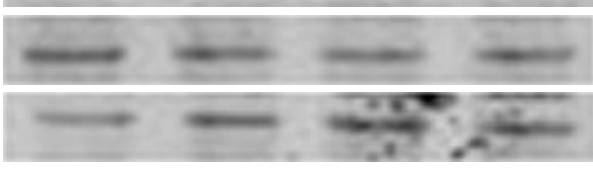

FIGURE 7. 4-(N-methyl-N-nitrosoamino)-1-(3-pyridyl)-1-butanone (NNK) activated nuclear factor (NF)-kB and extracellular signal-regulated kinase (ERK)1/2. a) Cells were treated with $10 \mu \mathrm{M} \mathrm{NNK}$ for 0-240 min. Western blotting was performed, in order to analyse levels of the NF-kB p65 subunit (65 kD) in the cytosol and the nucleus, and levels of phospho $(\mathrm{p})-\mathrm{I} \mathrm{B} \alpha$ and $\mathrm{I} \mathrm{K} \mathrm{B} \alpha(37 \mathrm{kD})$ in the cytosol. Equal loading was confirmed by probing with antibodies against actin in the cytosol and lamin $\mathrm{B}$ in the nucleus. b) Summary of the relative intensity of protein bands. The experiments were repeated twice and similar results were obtained. $\square: 0$ min; $1: 15$ min; $\mathbb{Z}: 30$ min; $\mathbf{\square}: 60$ min; $\mathbf{\square}$ $120 \mathrm{~min}$; 240 min. c-e) Control with no treatment. f-h) Cells were treated with $10 \mu \mathrm{M}$ NNK for $30 \mathrm{~min}$. An anti-p65 antibody was used in connection with a fluorescein isothiocyanate-conjugated secondary antibody ( $c$ and f). Propidium iodide was used for the counterstaining of the nucleus ( $d$ and g). e and h) The overlap of p65 and nuclear staining. The images are representative of three experiments. Scale bars $=10 \mu \mathrm{m}$. i) Cells were treated with $10 \mu \mathrm{M} N \mathrm{NK}$ for $0-24 \mathrm{~h}$. The nuclear proteins were extracted and $\mathrm{NF}-\mathrm{kB}$ transcriptional activity assays were performed. The data are represented as the mean $\pm \mathrm{SD}$ for four replicates of each treatment. The experiments were repeated twice with similar results. j) Cells were treated with $10 \mu \mathrm{M}$ NNK for 0-120 min. Levels of the phosphorylated (p) and dephosphorylated forms of ERK1/2 (42/44 kD), c-Jun NH $2^{-}$ terminal kinase (JNK; 46/54 kD) and p38 (38 kD) were determined by Western blot. Equal loading was confirmed by probing with antibiotics against actin. All experiments were repeated twice and similar results were obtained. 
a)

\begin{tabular}{l|llll} 
NNK & - & + & + & + \\
SN50 & - & - & + & - \\
U0126 & - & - & - & + \\
HO-1 & & & \\
p21 & & \\
C-IAP2 & & \\
Actin & & \\
Bad & & \\
Bcl-2 &
\end{tabular}

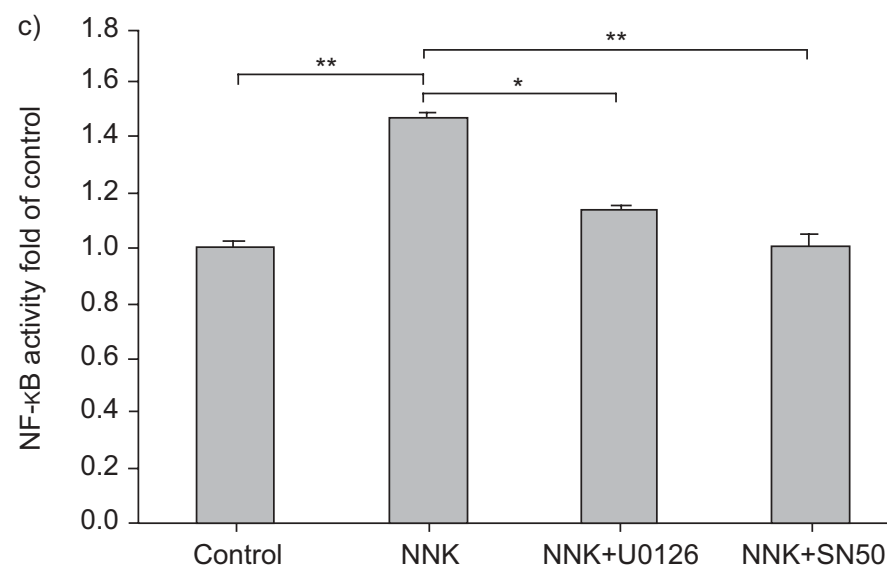

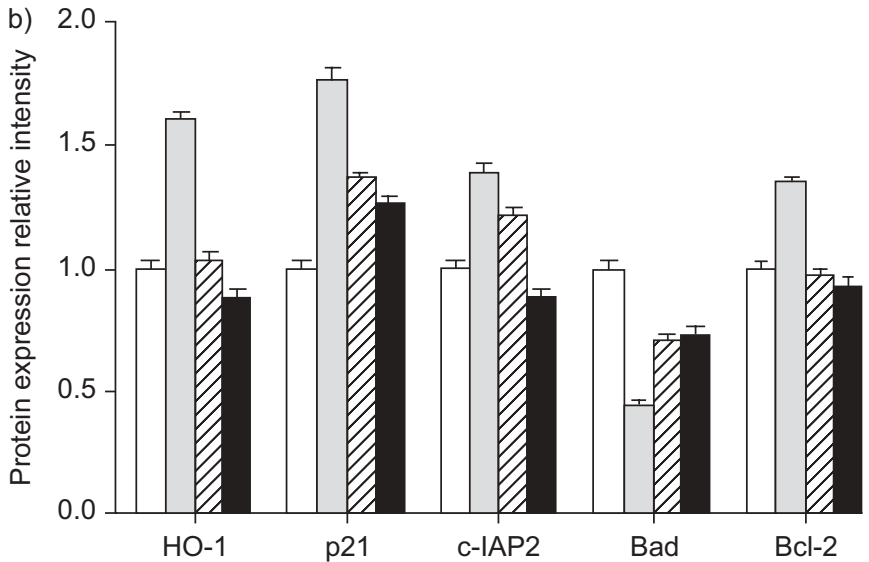

d)

NNK

U0126

SN50

p-ERK1/2

ERK1/2

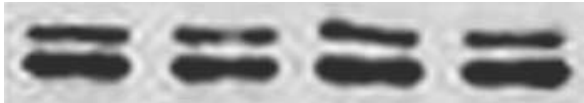

Actin

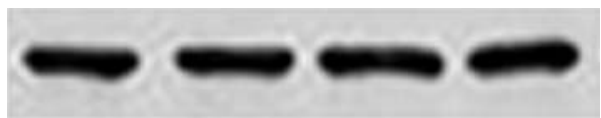

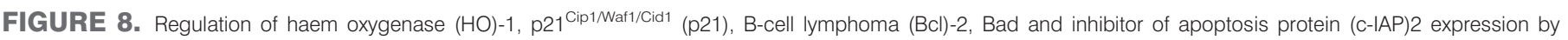
extracellular signal-regulated kinase (ERK)1/2 and nuclear factor (NF)-kB. a) Human nonsmall cell lung cancer cells, NCl-H23, were pre-treated with $10 \mu \mathrm{M}$ of the ERK1/2 inhibitor U0126 (A.G. Scientific Inc., San Diego, CA, USA) or $9 \mu \mathrm{M}$ of the NF-kB inhibitor SN50 for 30 min. This was followed by $10 \mu \mathrm{M}$ 4-(N-methyl-N-nitrosoamino)-1-(3pyridyl)-1-butanone (NNK) treatment for $8 \mathrm{~h}$ and $24 \mathrm{~h}$. Bcl-2 and Bad expression was measured in the cells treated for $8 \mathrm{~h}$ and HO-1, p21 and clAP-2 expression was measured in the cells treated for $24 \mathrm{~h}$. Cells without treatment were set up as control. Equal loading was confirmed by probing with antibodies against actin. b) Summary of the relative intensity of protein bands. The experiments were repeated twice and similar results were obtained. $\square$ : control; $:$ : NNK alone; $\mathbb{Z}:$ SN50 and NNK; $\mathbf{\square}:$ U0126 and NNK. c) Similar pre-treatment with U0126 or SN50 was followed by $10 \mu \mathrm{M}$ NNK treatment for $1 \mathrm{~h}$. Cells without treatment were set up as control. The nuclear protein was extracted for NF-kB DNA-binding activity assays. Data are expressed as the mean \pm sD fold induction compared with the control $(n=3)$. *: $p<0.05 ; * *: p<0.01$. $d)$ Similar pretreatment with U0126 or SN50 was followed by $10 \mu \mathrm{M}$ NNK treatment for 30 min. Cells without treatment were set up as control. The total protein was extracted for Western blot for phospho (p)-ERK1/2 and ERK1/2. Equal loading was confirmed by probing with antibodies against actin. The experiments were repeated twice and similar results were obtained.

signal-regulated kinase and nuclear factor- $\mathrm{kB}$, since the inhibition of either prevented the effect of NNK on haem oxygenase-1 expression. The elevation of haem oxygenase-1 by NNK may function to stimulate p21 expression, which subsequently inhibits Bcl-2, activates Bad and leads to the proliferation of lung cancer cells. Such a series of reactions is blocked when haem oxygenase- 1 is inhibited. The central role of haem oxygenase-1 in NNK-mediated lung carcinogenesis suggests that haem oxygenase- 1 could be a potential target in lung cancer prevention and treatment.

\section{ACKNOWLEDGEMENTS}

The authors would like to thank E. Chak (The Chinese University of Hong Kong, Sha Tin, Hong Kong) for technical assistance in immunochemical staining.

\section{REFERENCES}

1 Stellman SD, Takezaki T, Wang L, et al. Smoking and lung cancer risk in American and Japanese men: an international case-control study. Cancer Epidemiol Biomarkers Prev 2001; 10: 1193-1199. 
2 Hecht SS, Hoffmann D. Tobacco-specific nitrosamines, an important group of carcinogens in tobacco and tobacco smoke. Carcinogenesis 1988; 9: 875-884.

3 Hoffmann D, Rivenson A, Hecht SS. The biological significance of tobacco-specific $N$-nitrosamines: smoking and adenocarcinoma of the lung. Crit Rev Toxicol 1996; 26: 199-211.

4 Schuller HM. Mechanisms of smoking-related lung and pancreatic adenocarcinoma development. Nat Rev Cancer 2002; 2: 455-463.

5 Schuller HM, Plummer HK 3rd, Jull BA. Receptormediated effects of nicotine and its nitrosated derivative NNK on pulmonary neuroendocrine cells. Anat $\operatorname{Rec} A$ Discov Mol Cell Evol Biol 2003; 270: 51-58.

6 Sherr CJ, Roberts JM. CDK inhibitors: positive and negative regulators of G1-phase progression. Genes Dev 1999; 13: 1501-1512.

7 Hiyama H, Iavarone A, Reeves SA. Regulation of the cdk inhibitor p21 gene during cell cycle progression is under the control of the transcription factor E2F. Oncogene 1998; 16: 1513-1523.

8 Rosetti M, Zoli W, Tesei A, et al. Iressa strengthens the cytotoxic effect of docetaxel in NSCLC models that harbor specific molecular characteristics. J Cell Physiol 2007; 212: 710-716.

9 McCoubrey WK Jr, Huang TJ, Maines MD. Isolation and characterization of a cDNA from the rat brain that encodes hemoprotein heme oxygenase-3. Eur J Biochem 1997; 247: 725-732.

10 Maines MD, Abrahamsson PA. Expression of heme oxygenase-1 (HSP32) in human prostate: normal, hyperplastic, and tumor tissue distribution. Urology 1996; 47: 727-733.

11 Goodman AI, Choudhury M, da Silva JL, Schwartzman ML, Abraham NG. Overexpression of the heme oxygenase gene in renal cell carcinoma. Proc Soc Exp Biol Med 1997; 214: 54-61.

12 Liu ZM, Chen GG, Ng EK, Leung WK, Sung JJ, Chung SC. Upregulation of heme oxygenase-1 and p21 confers resistance to apoptosis in human gastric cancer cells. Oncogene 2004; 23: 503-513.

13 Chen GG, Liu ZM, Vlantis AC, Tse GM, Leung BC, van Hasselt CA. Heme oxygenase- 1 protects against apoptosis induced by tumor necrosis factor- $\alpha$ and cycloheximide in papillary thyroid carcinoma cells. J Cell Biochem 2004; 92: 1246-1256.

14 Chen Z, Hagler J, Palombella VJ, et al. Signal-induced sitespecific phosphorylation targets IкB- $\alpha$ to the ubiquitinproteasome pathway. Genes Dev 1995; 9: 1586-1597.

15 Cavin LG, Romieu-Mourez R, Panta GR, et al. Inhibition of CK2 activity by TGF- $\beta 1$ promotes I $\mathrm{KB}-\alpha$ protein stabilization and apoptosis of immortalized hepatocytes. Hepatology 2003; 38: 1540-1551.

16 Hideshima T, Chauhan D, Hayashi T, et al. Proteasome inhibitor PS-341 abrogates IL-6 triggered signaling cascades via caspase-dependent downregulation of gp130 in multiple myeloma. Oncogene 2003; 22: 8386-8393.

17 Keshamouni VG, Reddy RC, Arenberg DA, et al. Peroxisome proliferator-activated receptor- $\gamma$ activation inhibits tumor progression in non-small-cell lung cancer. Oncogene 2004; 23: 100-108.
$18 \mathrm{Yu}$ W, Liao QY, Hantash FM, Sanders BG, Kline K. Activation of extracellular signal-regulated kinase and cJun- $\mathrm{NH}_{2}$-terminal kinase but not p38 mitogen-activated protein kinases is required for RRR- $\alpha$-tocopheryl succinateinduced apoptosis of human breast cancer cells. Cancer Res 2001; 61: 6569-6576.

19 Li M, Lee TW, Mok TS, Warner TD, Yim AP, Chen GG. Activation of peroxisome proliferator-activated receptor- $\gamma$ by troglitazone (TGZ) inhibits human lung cell growth. J Cell Biochem 2005; 96: 760-774.

20 Chen GG, Lai PB, Chak EC, Xu H, Lee KM, Lau WY. Immunohistochemical analysis of pro-apoptotic Bid level in chronic hepatitis, hepatocellular carcinoma and liver metastases. Cancer Lett 2001; 172: 75-82.

21 Li M, Lee TW, Yim AP, Mok TS, Chen GG. Apoptosis induced by troglitazone is both peroxisome proliferatoractivated receptor- $\gamma$ - and ERK-dependent in human nonsmall lung cancer cells. J Cell Physiol 2006; 209: 428-438.

22 Proulx LI, Gaudreault M, Turmel V, Augusto LA, Castonguay A, Bissonnette EY. 4-(Methylnitrosamino)-1(3-pyridyl)-1-butanone, a component of tobacco smoke, modulates mediator release from human bronchial and alveolar epithelial cells. Clin Exp Immunol 2005; 140: 46-53.

23 Proulx LI, Paré G, Bissonnette EY. Alveolar macrophage cytotoxic activity is inhibited by 4-(methylnitrosamino)-1(3-pyridyl)-1-butanone (NNK), a carcinogenic component of cigarette smoke. Cancer Immunol Immunother 2007; 56: 831-838.

24 Print CG, Loveland KL, Gibson L, et al. Apoptosis regulator bcl-w is essential for spermatogenesis but appears otherwise redundant. Proc Natl Acad Sci USA 1998; 95: 12424-12431.

25 Scheid MP, Schubert KM, Duronio V. Regulation of bad phosphorylation and association with $\mathrm{Bcl}-\mathrm{X}_{\mathrm{L}}$ by the MAPK/Erk kinase. J Biol Chem 1999; 274: 31108-31113.

26 Rioux N, Castonguay A. The induction of cyclooxygenase-1 by a tobacco carcinogen in U937 human macrophages is correlated to the activation of NF- $\kappa B$. Carcinogenesis 2000; 21: 1745-1751.

27 Ye YN, Liu ES, Shin VY, Wu WK, Cho CH. The modulating role of nuclear factor- $\kappa \mathrm{B}$ in the action of $\alpha 7$-nicotinic acetylcholine receptor and cross-talk between 5-lipoxygenase and cyclooxygenase- 2 in colon cancer growth induced by 4-(N-methyl-N-nitrosamino)-1-(3-pyridyl)-1-butanone. J Pharmacol Exp Ther 2004; 311: 123-130.

28 Sawhney M, Rohatgi N, Kaur J, et al. Expression of NF- $\kappa B$ parallels COX-2 expression in oral precancer and cancer: association with smokeless tobacco. Int J Cancer 2007; 120: 2545-2556.

29 Hirai K, Sasahira T, Ohmori H, Fujii K, Kuniyasu H. Inhibition of heme oxygenase- 1 by zinc protoporphyrin IX reduces tumor growth of LL/2 lung cancer in C57BL mice. Int J Cancer 2007; 120: 500-505.

30 Pahl HL. Activators and target genes of Rel/NF- $\kappa B$ transcription factors. Oncogene 1999; 18: 6853-6866.

31 Ho YS, Chen CH, Wang YJ, et al. Tobacco-specific carcinogen 4-(methylnitrosamino)-1-(3-pyridyl)-1-butanone (NNK) induces cell proliferation in normal human bronchial epithelial cells through NF- $\mathrm{BB}$ activation and cyclin D1 up-regulation. Toxicol Appl Pharmacol 2005; 205: 133-148. 
32 Denlinger CE, Rundall BK, Jones DR. Modulation of antiapoptotic cell signaling pathways in non-small cell lung cancer: the role of NF-кB. Semin Thorac Cardiovasc Surg 2004; 16: 28-39.

33 Tsurutani J, Castillo SS, Brognard J, et al. Tobacco components stimulate Akt-dependent proliferation and NF-кB-dependent survival in lung cancer cells. Carcinogenesis 2005; 26: 1182-1195.

34 Russell MA, Jarvis M, Iyer R, Feyerabend C. Relation of nicotine yield of cigarettes to blood nicotine concentrations in smokers. Br Med J 1980; 280: 972-976.

35 Turner DM, Armitage AK, Briant RH, Dollery CT. Metabolism of nicotine by the isolated perfused dog lung. Xenobiotica 1975; 5: 539-551.

36 Gong P, Cederbaum AI, Nieto N. Increased expression of cytochrome P450 2E1 induces heme oxygenase-1 through ERK MAPK pathway. J Biol Chem 2003; 278: 2969329700.

37 Benvenisti-Zarom L, Chen-Roetling J, Regan RF. Inhibition of the ERK/MAP kinase pathway attenuates heme oxygenase-1 expression and heme-mediated neuronal injury. Neurosci Lett 2006; 398: 230-234.

38 LaRue KE, Khalil M, Freyer JP. Microenvironmental regulation of proliferation in multicellular spheroids is mediated through differential expression of cyclin-dependent kinase inhibitors. Cancer Res 2004; 64: 1621-1631.
39 Bae KM, Wang H, Jiang G, Chen MG, Lu L, Xiao L. Protein kinase $C \varepsilon$ is overexpressed in primary human non-small cell lung cancers and functionally required for proliferation of non-small cell lung cancer cells in a p21/Cip1dependent manner. Cancer Res 2007; 67: 6053-6063.

40 Dent P, Grant S. Pharmacologic interruption of the mitogen-activated extracellular-regulated kinase/mitogenactivated protein kinase signal transduction pathway: potential role in promoting cytotoxic drug action. Clin Cancer Res 2001; 7: 775-783.

41 Zhang X, Shan P, Qureshi S, et al. Cutting edge: TLR4 deficiency confers susceptibility to lethal oxidant lung injury. J Immunol 2005; 175: 4834-4838.

42 Pozo-Guisado E, Merino JM, Mulero-Navarro S, et al. Resveratrol-induced apoptosis in MCF-7 human breast cancer cells involves a caspase-independent mechanism with downregulation of Bcl-2 and NF-кB. Int J Cancer 2005; 115: 74-84.

43 Jin Z, Xin M, Deng X. Survival function of protein kinase $\mathrm{Cl}_{1}$ as a novel nitrosamine 4-(methylnitrosamino)-1-(3pyridyl)-1-butanone-activated bad kinase. J Biol Chem 2005; 280: 16045-16052.

44 Erhardt P, Schremser EJ, Cooper GM. B-Raf inhibits programmed cell death downstream of cytochrome $\mathrm{C}$ release from mitochondria by activating the MEK/Erk pathway. Mol Cell Biol 1999; 19: 5308-5315. 